\title{
The Cause of Cancer
}

$D^{\mathrm{R}}$ R. W. E. GYE,* rightly we believe, thinks that the problem of the causation of cancer is at present most likely to be solved by studying the malignant tumours of fowls first described by Rous twenty years ago. Ordinary mammalian tumours, either arising spontaneously or induced by tarring or other irritating procedures, can be transmitted from one animal to another only by transplanting living tumour cells. The Rous tumours are peculiar in that they can be transmitted by means of dead cells; by cell-free extracts, and by such extracts after they have been passed through fine filters which will detain ordinary bacteria. In other words, the filtrates contain some carcinogenic agent which resembles an ultramicroscopic virus, and Drs. Gye and Purdy now give an account of the multitudinous experiments which they have made in an attempt to ascertain the nature of this agent.

In Gye's original paper published in 1925, he advanced the view that the agent is made up of two factors: one, the virus, can be killed by chloroform or acriflavine; the other, the specific or intrinsic factor, is a labile unorganised substance easily destroyed by gentle heating. An extract inactivated by chloroform could be reactivated by the addition of an extract inactivated by heat. He also found that an extract of a Rous tumour which had been chloroformed could be activated by a heated extract of several mammalian tumours, and would produce a Rous tumour on inoculation into a chicken. Whence he concluded that there was a general non-specific virus which might cause any tumour if it could co-operate with the specific factor which was responsible for the maintenance of the characteristic histological constitution so definitely characteristic of all transmissible neoplasms. The virus was looked upon as an independent organism coming into the body from outside, the specific factor as something arising in the cells of the affected animal.

As the result of a great deal of further work, in which his exacting standard of technical rectitude is fully maintained, Dr. Gye is still of opinion that this interpretation is in the main correct, but he admits that its original experimental basis has proved less secure than he had supposed. Extracts can be inactivated with certainty and regularity by mild heat, but he has found that the actions of phenol, acriflavine, and chloroform are less dependable and that extracts which have been treated with these antiseptics in such a way that they can be relied upon to be inactivated every time the experiment is tried cannot be reactivated by heated extract. "Antiseptics", as he says, "kill the virus only a very little more readily than they destroy the intrinsic substance." Hence it is impossible to get a long series of consistent clean-cut results which will convince the

* The Cause of Cancer. By Dr. W. E. Gye and W. J. Purdy. Pp. xiv +515 . (London, Toronto, Melbourne and Sydney: Cassell and Co., Ltd., 1931.) 30 s. net. sceptic, though the mass effect leaves the author's own opinion much as it was.

Dr. Gye then turns to immarological observations and describes a long series of experiments on the properties of the blood serum of animals which have been injected with tumour extracts. This section of the book (p. 307 onwards) contains a great number of important and interesting data in a field which has been little explored, and their apprehension is greatly helped by exceptionally clear diagrams. A detailed summary is impossible, but the chief conclusion which emerges is that the sera of the inoculated animals contain two different antibodies, one of which renders an active tumour extract ineffective after it has been heated to $55^{\circ} \mathrm{C}$. for half an hour (that is, in bacteriological language, in the absence of complement), while the other neutralises the extract only if fresh serum (complement) is present. If there are two antibodies, there are presumably two antigens: which confirms the original hypothesis of a dual agent.

A second discovery of moment is that the sera of goats repeatedly injected with extracts of normal chick embryos will neutralise active extracts of Rous tumour in the presence, but not in the absence, of fresh serum, and that this property can be abstracted from the sera by adsorption with minced chick embryo. Embryo also removes the antibody which needs the presence of fresh serum from the sera of goats inoculated with Rous extracts, but has no effect on the antibody which is active in the absence of fresh serum: the former is the antibody to the specific factor, the latter to the virus. Anti-Rous sera also inactivate extracts of other fowl tumours of quite different histological structure, which therefore presumably contain the same virus; in one instance this does not happen in the absence of fresh serum, and hence the virus is judged to be different.

Such in brief are Dr. Gye's main results and inferences. He has much evidence in their favour, but there is obviously a good deal that needs further explanation, and the experiments do not always seem consistent among themselves. As he himself says, the method of testing by inoculating fowls is at best calculated to reveal only coarse differences, and the effect of some tumour extracts is complicated by the presence of elusive "inhibitory substances". The serum from normal guinea-pigs, goats, and fowls occasionally neutralises active extract; ducks injected with Rous extracts yield sera on which complement has no effect; rabbits generally produce no antibodies; goats generate both antibodies; a horse showed both antibodies and indications of a third. A goat immunised with Rous filtrates was bled on July 25 and the serum tested next day was found to be active only in the presence of complement (p. 344); serum obtained from the same animal on June 30 and tested on Aug. 29 neutralised well in the absence of complement.

It may be that curiosities and apparent dis- 
crepancies such as these are the necessary consequences of not having always an infecting extract of standard strength against which to test the sera, but it is difficult to get rid of a suspicion that the distinction made between the two antibodies is quantitative rather than qualitative, and that their relation to fresh serum is not that of immune body and complement as known in bacteriology. The whole narrative needs, deserves, and will doubtless receive detailed critical analysis: it is fortunate that the data are presented on such an ample scale that this is possible. The interpretation seems also in places to be inconsistent. Thus on p. 354 it is pointed out that two goats injected with heated extract (that is, containing virus only) produced sera which were active only in the presence of complement and therefore contained antiviral bodies only, and that this assumption is in accordance with general bacteriological experience. It is difficult to see how this fits with the fact (p. 361) that anti-normal-embryo sera are also active only if fresh serum is present. On p. 421 the antibody which operates in the absence of fresh serum is definitely identified with the extrinsic factor, that is, the virus. Nor is it possible to subscribe to Dr. Gye's suggestion that his immunological experiments demonstrate that extracts of fowl tumours contain some antigen which cannot have originated in the fowl and must therefore be an extrinsic virus which he thinks is widely disseminated about the world. Immunological differences between proteins depend on differences in chemical structure rather than on differences of biological origin, though in a rough way the two generally go together. Antigens from different species may be indistinguishable (blood serum of sheep and goat, egg albumin of duck and hen, various caseinogens), while antigens from the same species may be different (for example, the proteins of blood plasma or egg white) and the proteins of the lens of the eye may be antigenic in the individual to whom the eye belongs.

It seems evident that this part of Dr. Gye's argument will not carry anything like the weight that he has put on it. What his observations do seem to show quite clearly is that part at any rate of the agent is intrinsic-a conclusion in good accord with the old-fashioned view that cancer is a local autochthonous disease.

\section{Scientific Research and National Life*}

$\mathrm{T}^{\mathrm{H}}$ HE sixteenth Annual Report of the Department of Scientific and Industrial Research covers the period Aug. 1, 1930-July 31, 1931. It includes the brief report of the Privy Council, signed by the Right Hon. Stanley Baldwin, and the longer report of the Advisory Council, over Lord Rutherford's signature, which surveys the development of the Department and emphasises the need for scientific method in industry. Summaries of the work carried out by the National Physical Laboratory, the Chemical Research Laboratory, the research associations, and under the direction of some forty-five research boards and committees are attached, together with appendices dealing with finance, publications, and the personnel of the various boards and committees. The report presents an impressive picture of the contribution which science is making to the major needs of the population, promoting not merely material development, but also the growth of a better and healthier social order. Not only the research associations, but also the long list of committees and boards, many of whose distinguished members are rendering voluntary service which is little recognised, may be regarded as a great general staff organised for the application of science to the myriad needs of modern society.

In view of the curtailment of expenditure by the Committee of the Privy Council, particular attention is attracted to the expenditure detailed in the present report. The gross estimate for the year is

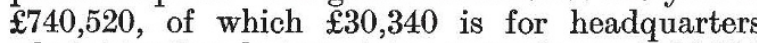
administration, but receipts amounting to $£ 184,829$ bring the net expenditure to $£ 555,691$. Grants for

* Department of Scientific and Industrial Research. Report for the Year 1930-31. (Cmd. 3989.) Pp. iv + 186. (London: H.M. Stationery Office, 1931.) 3s. net. research account for an expenditure of $£ 40,610$, gross, the Geological Survey and the Museum of Practical Geology for $£ 67,714$, and grants to research associations for $\mathfrak{£ 7 5 , 6 5 5}$. The National Physical Laboratory represents a gross expenditure of $£ 208,964$, of which slightly more than half, $£ 104,706$, is recovered as receipts from outside bodies and firms, the Air Ministry, and other government departments or special research funds. The Chemical Research Laboratory represents a charge of $£ 19,993$ net, building research, $£ 30,421$ net, fuel research, $£ 87,411$ net, radio research, $£ 12,066$ net, water pollution, $£ 10,020$ net. More than threequarters of the expenditure of $£ 50,060$ on food investigation is borne by receipts, the net cost to the State being $\mathfrak{1 1}, 693$. Receipts amounting to $£ 6936$ similarly reduce the expenditure on forest products research to $£ 36,376$.

The expenditure on research associations, of which twenty-one received grants during the year, is of special interest. The seven largest grants, of

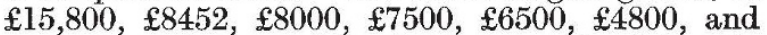
$\mathbf{\$ 4 7 5 0}$, are those paid to the Cotton, the Scientific Instruments, the Non-Ferrous Metals, the Wool Industries Research Association, the National Federation of Iron and Steel Manufacturers (Industrial Research Council), the Cast Iron Research Association, and the Research Association of the British Paint, Colour, and Varnish Manufacturers. The British Photographic Research Association was liquidated on Nov. 7, 1930, and its functions have now been taken over by the research establishments of the rationalised photographic industry. Thus

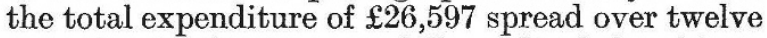
years has in this instance fully realised the objects of the Government scheme, and paved the way for

$$
\text { No. 3252, VoL. 129] }
$$

